\title{
Elisa detection of grapevine fleck virus (GFkV)
}

\author{
B Walter, P Cornuet \\ INRA Colmar, Laboratoire de Pathologie Végétale, Vigne et Vin, BP 507, F68021 Colmar, France
}

(Received 3 February 1993; accepted 12 May 1993)

\begin{abstract}
Summary - The association of grapevine fleck virus (GFkV) with fleck symptoms on grapevine was established using Elisa. The results confirmed that GFkV is probably the virus responsible for fleck. Its detection in vines by Elisa was not reliable throughout the vegetative cycle: under our conditions, in Alsace, June-July was found to be the best period for testing.
\end{abstract}

grapevine / virus / fleck / Elisa / etiology

Résumé - Détection par Elisa du virus de la marbrure de la vigne (GFkV = grapevine fleck virus). L'association du Grapevine fleck virus (GFkV) avec les symptômes de la marbrure de la vigne a été établie par Elisa. La détection par Elisa du GFkV dans les plants de vigne n'est pas possible pendant la totalité du cycle végétatif : dans nos conditions, en Alsace, les mois de juin et juillet constituent la meilleure période pour le dépistage.

vigne / virus / marbrure / Elisa / étiologie

\section{INTRODUCTION}

Detection of pathogens which are transmissible through the wood (viruses, mollicutes, bacteria) is an essential step in the selection of the grapevine (Walter, 1991a). More than 30 major virus and virus-like diseases of grapevines have been described (Bovey and Martelli, 1992). Among them, nepoviruses and closteroviruses are well characterized and can be detected by Elisa or molecular hybridization techniques. The viruslike disease are detected by grafting onto indexing varieties (Walter, 1991b).

Only recently a phloem-limited non-mechanically transmissible isometric virus was demonstrated to be associated with grapevine fleck disease (Boscia et al, 1991a,b).

Fleck disease is latent in European grapevine varieties and in most American rootstocks. The following symptoms develop on Vitis rupestris used as indexing variety: clearing of veinlets and translucent spots, wrinkling and upward curling of the leaves. The disease can strongly affect root development of rootstocks as well as their grafting ability (Triolo and Materazzi, 1986). No vector is known and dissemination is primarily through infected propagation material. Seed transmission does not occur. The disease can be eliminated by heat therapy or meristem tip culture (Goheen and Luhn, 1973; Ottenwaelter et al, 1973; Barlass et al, 1982).

In France, sanitary certification presently requires freedom from fanleaf, leafroll, corky bark, Rupestris stem pitting and Kober stem grooving for rootstocks and $V$ vinifera. In addition, fleck has to be absent from rootstock varieties.

In the present paper we describe the purification of grapevine fleck virus (GFkV) from roots and leaves of infected grapevines and the development of Elisa for routine detection of the virus. 


\section{MATERIALS AND METHODS}

\section{Source material}

Different Vitis spp accessions obtained from INRA Vassal were used for purification of the virus. After preliminary assays, $V$ vinifera cv Bogaskere (accession Y200) was chosen. Y200 indexed positive on $V$ rupestris and was also infected by vein mosaic and vein necrosis but was free from fanleaf and arabis mosaic viruses, leafroll, corky bark, Rupestris stem pitting and Kober stem grooving.

For Elisa, we used other Vitis spp from collections (INRA Vassal, INRA Colmar, INRA Bordeaux) and, in some cases, plants obtained after heat treatment and in vitro culture of shoot apices of fleck-diseased mother plants (Bass and Legin, 1981).

\section{Indexing}

Detection of fleck disease was made by grafting onto Vitis rupestris du Lot, either by using woody cuttings or by green grafting as described by Walter et al (1990).

\section{Virus purification}

The purification procedure was basically the same as that described by Boulila et al (1990) using fresh young and fast growing rootlets or leaves of greenhouse-forced cuttings of the donor vine. After polyethyleneglycol precipitation (PEG 6.000) and highspeed centrifugation, the virus suspension was centrifuged through different types of gradients.

Sucrose gradients were formed by 3 layers of 15,25 and $35 \%$ sucrose in citrate buffer $0.02 \mathrm{M} \mathrm{pH} 6.1$, left to diffuse overnight at $4^{\circ} \mathrm{C}$; centrifugation was for $150 \mathrm{~min}$ at $24000 \mathrm{rpm}$ in a Beckman SW 28 rotor at $5^{\circ} \mathrm{C}$.

Nicodenz (Sigma) gradients were constituted of 4 layers, each $1 \mathrm{ml}$, of $60,50,40$ and $30 \%$ with an upper layer of $6 \mathrm{ml} 5 \%$ Nicodenz in citrate buffer, centrifuged for $18 \mathrm{~h}$ at $31000 \mathrm{rpm}$ at $5^{\circ} \mathrm{C}$ in Beckman SW 41 tubes.

Cesium sulfate was used at $1.4 \mathrm{~g} / \mathrm{cm}^{3}$ in citrate buffer and centrifuged in a Beckman SW 41 rotor for $17 \mathrm{~h}$ at $35000 \mathrm{rpm}$ at $5^{\circ} \mathrm{C}$.

The virus was obtained from the fractions of the gradients after dialysis in citrate buffer and high-speed centrifugation (Beckman $50.2 \mathrm{Ti}, 2 \mathrm{~h}, 250000 \mathrm{~g}, 5^{\circ} \mathrm{C}$ ).

\section{Electron microscopy}

Carbon-coated pioloform (Agar Scientific $R$ 1275) grids were floated for 15 min on a drop of virus sus- pension. After dessication, staining was made on a drop of $2 \%$ aqueous uranyl acetate. The preparations were observed with a Hitachi HU 11 CS microscope.

\section{Serology}

The first assays were made with an antiserum obtained from GP Martelli (University of Bari, Italy).

To prepare antisera, purified virus preparations from sucrose or Nicodenz gradients were emulsified with complete (for the first injection) or incomplete (for booster injections) Freund's adjuvant. Rabbits were injected subcutaneously at 7-d intervals. Antiserum collection began $14 \mathrm{~d}$ after the third injection. Immunoglobulins were purified by the rivanol precipitation method (Hardie and Van Regenmortel, 1977). Conjugation of purified immunoglobulins with alkaline phosphatase or biotin was made using $0.06 \%$ glutaraldehyde (Avrameas, 1969).

\section{Detection of GFkV in grapevines}

Fresh leaves or cortical scrapings were crushed in the presence of 5 vol Tris- $\mathrm{HCl} 0.2 \mathrm{M}$ buffer $\mathrm{pH} 8.2$ containing $2 \%$ polyvinylpyrrolidone, $0.8 \% \mathrm{NaCl}$ and $0.05 \%$ Tween 20 . In some cases, this extract was serially diluted from $10^{-1}$ to $10^{-5}$ in the same buffer. For Elisa, coating immunoglobulins at $0.25 \mu \mathrm{g} / \mathrm{ml}$ were incubated for $3 \mathrm{~h}$ at $37^{\circ} \mathrm{C}$. After overnight incubation of the plant extract at $4^{\circ} \mathrm{C}$, an immunoglobulin-biotin conjugate (in some cases pre-adsorbed with $5 \% \mathrm{v} / \mathrm{v}$ healthy grapevine extract) was added for $2 \mathrm{~h}$ at $38^{\circ} \mathrm{C}$. Detection was with a streptavidin-alkaline phosphatase conjugate (Interchim Jackson) at $1 / 10000$ for 30 min and paranitrophenylphosphate at $1 \mathrm{mg} / \mathrm{ml}$ at $38^{\circ} \mathrm{C}$.

\section{RESULTS}

\section{Virus purification}

Elisa (fig 1) and EM observations of sucrose gradient fractions showed that 2 zones were enriched with GFkV particles. An intermediate step in the purification consisting of clarification with ether (1 v/1 v) or butanol (8.5\%; v/v) after PEG precipitation and before high-speed centrifugation, yielded more highly purified virus suspensions.

Virus particles were paraspheric, $\approx 30 \mathrm{~nm}$ in diameter, some appearing empty, others apparently intact (fig 2). 


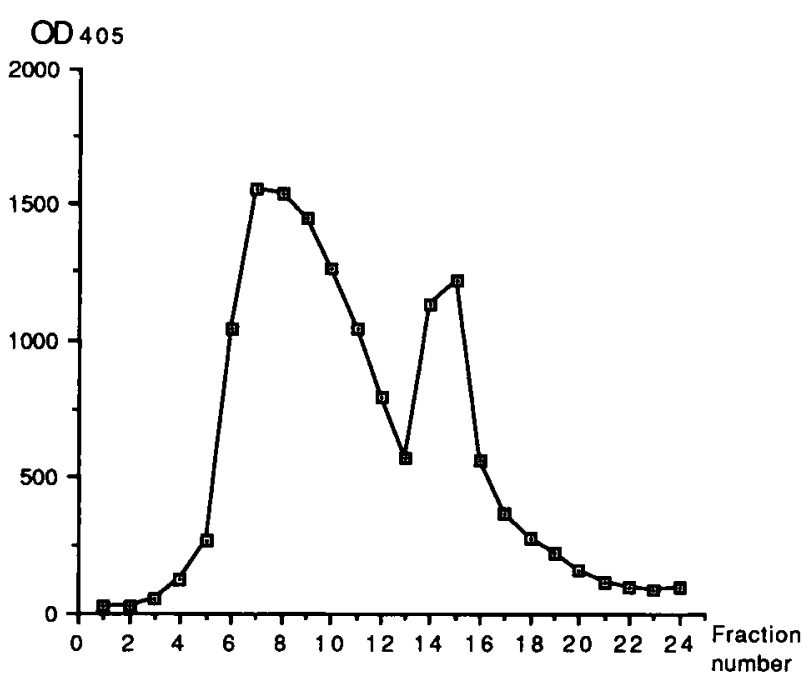

Fig 1. Elisa detection of GFkV in sucrose gradient fractions. For the purification, leaf extract was PEG-precipitated, clarified with butanol and centrifuged at $200000 \mathrm{~g}$ for $90 \mathrm{~min}$. The pellet was resuspended in citrate buffer $0.02 \mathrm{M} \mathrm{pH} 6.1$ and $1-\mathrm{ml}$ suspension (corresponding to $250 \mathrm{~g}$ leaves) was centrifuged in a Beckman SW 28 rotor at $24000 \mathrm{rpm}$ for $150 \mathrm{~min}$ at $5^{\circ} \mathrm{C}$ through a gradient obtained after overnight diffusion of 3 layers of 35,25 and $15 \%$ sucrose in citrate buffer. Centrifugation was from left to right. Each gradient fraction was diluted $1 / 50$ in Tris- $\mathrm{HCl}$ buffer. Data are OD readings at $405 \mathrm{~nm}$, after $1-\mathrm{h}$ incubation of the substrate.

\section{Association of GFkV with fleck symptoms}

A very good correlation was found between the presence of fleck symptoms following indexing on $V$ rupestris and positive Elisa response: 25 accessions from various geographical origins, which included $V$ vinifera and rootstock hybrids, were positive in both tests; 95 were negative in both; 3 were positive by indexing but negative by Elisa and 6 were positive by Elisa but negative by indexing.

Plants obtained after in vitro culturing of shoot tips from heat-treated vines (65 $V$ rupestris and $23 V$ vinifera Muscat d'Alexandrie) had been found to be free from fleck after $>30$ d treatment at $35^{\circ} \mathrm{C}$ (Bass and Legin, 1981). The absence of fleck as revealed by absence of symptoms (table I) or negative indexing (table II) was highly correlated with the absence of GFkV in Elisa. Only 2 plants of cr Muscat d'Alexandrie indexing negative on $V$ rupestris after $50 \mathrm{~d}$ heat treatment were positive in Elisa (table II). This difference may be due to a lower sensitivity of indexing compared to Elisa, or to a natural reinfection of these 2 plants that were indexed immediately after planting outdoors, whereas they were checked by Elisa some years later.

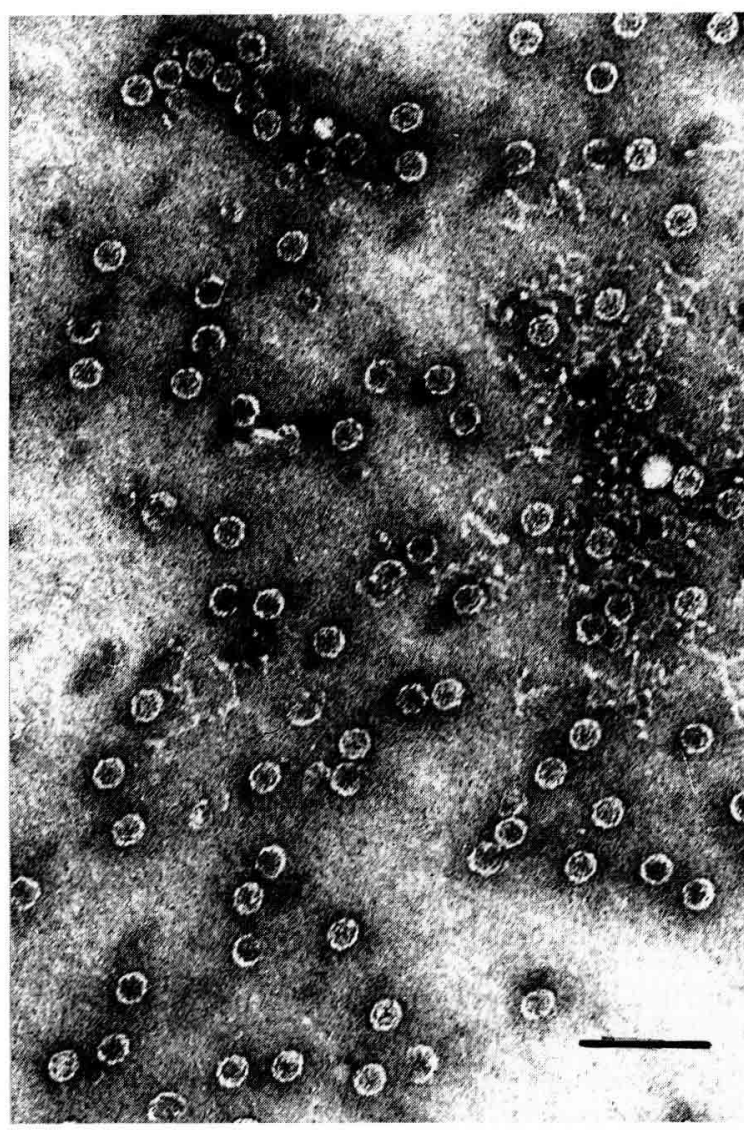

Fig 2. Electron micrograph of a Nycodenz gradient fraction enriched in GFkV after staining with aqueous uranyl acetate. Bar: $100 \mathrm{~nm}$ (photo courtesy of G Stocky).

\section{Distribution of virus in plants}

In the first experiment in May, very young leaves and cortical scrapings of $V$ vinifera Muscat d'Alexandrie and $V$ rupestris were extracted and

Table I. Presence of GFkV in Vitis rupestris with and without symptoms after increasing periods of heat treatment at $35^{\circ} \mathrm{C}$.

\begin{tabular}{crr} 
Heat treatment $(d)$ & Symptoms & Elisa \\
\hline 0 & $21+$ & $21+$ \\
& $3-$ & $3-$ \\
26 & $9+$ & $9+$ \\
156 & $13-$ & $13-$ \\
184 & $6-$ & $6-$ \\
382 & $13-$ & $13-$
\end{tabular}


Table II. Presence of GFkV in Vitis vinifera (Muscat d'Alexandrie) that indexed positive or negative on $V$ rupestris after increasing periods of heat treatment at $35^{\circ} \mathrm{C}$.

\begin{tabular}{lll} 
Heat treatment $(d)$ & IndexN rupestris & Elisa \\
\hline 21 & $3+$ & $3+$ \\
36 & $2+$ & $2+$ \\
& $2-$ & $2-$ \\
50 & $4+$ & $4+$ \\
& $9-$ & $7-2+$ \\
426 & $3-$ & $3-$ \\
\hline
\end{tabular}

sap dilutions from $10^{-1}$ to $10^{-5}$ were assayed in Elisa. For Muscat, the $10^{-5}$ dilution of leaf extracts consistently gave a positive reaction, whereas cortical scraping extract only reacted up to 10-3. In contrast, leaves of $V$ rupestris reacted to a dilution of $10^{-1}$ and cortical scrapings up to $10^{-2}$. These differences were confirmed when comparing optical density (OD) readings (table III).

In the second experiment, half of a Muscat d'Alexandrie plant was harvested on September 30, 1992 and cortical scrapings, petioles and leaves were analyzed by Elisa. The sample con-

Table III. Distribution of GFkV in young leaves and wood shavings harvested in May. Data are Elisa OD readings of various dilutions of the extracts.

$\begin{array}{cc}\begin{array}{c}\text { V vinifera } \\ \text { Muscat d'Alexandrie }\end{array} & \begin{array}{c}\text { V rupestris } \\ d u \text { Lot }\end{array} \\ & \text { Leaves Wood }\end{array}$

Fleck

$\begin{array}{rrrrr}10^{-1} & >2.000 & 1.673 & 0.503 & 0.956 \\ 10^{-2} & >2.000 & 0.778 & 0.092 & 0.399 \\ 10^{-3} & 1.128 & 0.203 & 0.046 & 0.099\end{array}$

Control

$\begin{array}{lllll}10^{-1} & 0.045 & 0.068 & 0.094 & 0.122\end{array}$

sisted of a main branch from which cortical scrapings were harvested near the beginning of 41 -yr-old branches that were numbered 1 to 4 from the bottom to the top of the main branch. From each 1-yr-old cane, cortical scrapings, petioles and leaves were collected from the bottom, middle and apical portions (table IV). OD readings ranged from 0.348 to 1.243 in leaf extracts but no conclusion could be drawn about the distribution of the virus in the plant. In petioles and cortical scrapings, Elisa readings were more consistent.

In the third experiment (October 10, 1992) leaves, petioles and cortical scrapings from the bottom, middle and top parts of 4 canes of Vitis rupestris were analyzed (table V). Cortical scrapings did not show significant variations, whereas petioles and leaves gave increasing readings from the bottom to the top of the canes.

Table IV. Distribution of GFkV in leaves, petioles and wood shavings of different portions of 1-yr-old canes and main branch of Vitis vinifera Muscat d'Alexandrie.

\begin{tabular}{lllll}
\hline $\begin{array}{l}\text { Portion } \\
\text { of cane }\end{array}$ & Cane 1 & Cane 2 & Cane 3 & Cane 4 \\
\hline Top & & & & \\
& & & & \\
Leaves & 1.045 & 0.348 & 0.590 & 1.013 \\
Petioles & 0.671 & 0.618 & 0.701 & 0.853 \\
Wood & 1.000 & 0.700 & 0.806 & 0.963
\end{tabular}

Middle

$\begin{array}{lllll}\text { Leaves } & 1.077 & 1.015 & 1.043 & 0.944 \\ \text { Petioles } & 1.004 & 0.868 & 0.769 & 0.867 \\ \text { Wood } & 0.887 & 0.954 & 1.040 & 0.903\end{array}$

Bottom

\begin{tabular}{lllll} 
Leaves & 0.779 & 0.813 & 0.746 & 1.243 \\
Petioles & 0.929 & 0.782 & 0.917 & 0.777 \\
Wood & 1.014 & 1.090 & 0.965 & 0.901 \\
& & & & \\
Main branch & 1.082 & 0.971 & 0.689 & - \\
\hline
\end{tabular}

Data are Elisa OD readings of $1 / 10$ extracts after $1-h$ incubation of nitrophenylphosphate. Healthy controls: leaves = 0.023 ; petioles $=0.016 ;$ wood $=0.015$. Buffer control $=0.013$. 
Table V. Distribution of GFkV in leaves, petioles and wood shavings of different portions of 1-yr-old canes of Vitis rupestris du Lot.

\section{Portion Cane 1 Cane 2 Cane 3 Cane 4} of cane

$\begin{array}{lllll}\text { Top } & & & & \\ \text { Leaves } & 0.715 & 0.847 & 0.850 & 0.885 \\ \text { Petioles } & 0.582 & 0.800 & 0.558 & 0.578 \\ \text { Wood } & 0.756 & 0.891 & 0.754 & 0.771 \\ \text { Middle } & & & & \\ \quad \text { Leaves } & 0.779 & 0.752 & 0.589 & 0.529 \\ \text { Petioles } & 0.516 & 0.482 & 0.377 & 0.439 \\ \text { Wood } & 0.635 & 0.848 & 0.825 & 0.779 \\ \text { Bottom } & & & & \\ \text { Leaves } & 0.298 & 0.398 & 0.458 & 0.429 \\ \text { Petioles } & 0.503 & 0.371 & 0.408 & 0.476 \\ \text { Wood } & 0.852 & 0.958 & 0.796 & 0.789\end{array}$

Data are Elisa OD readings of $1 / 10$ extracts after $1-h$ incubation of nitrophenylphosphate. Healthy controls: leaves = 0.098 ; petioles $=0.045 ;$ wood $=0.008$. Buffer control $=0.007$.

(A) Muscat d'Alexandrie

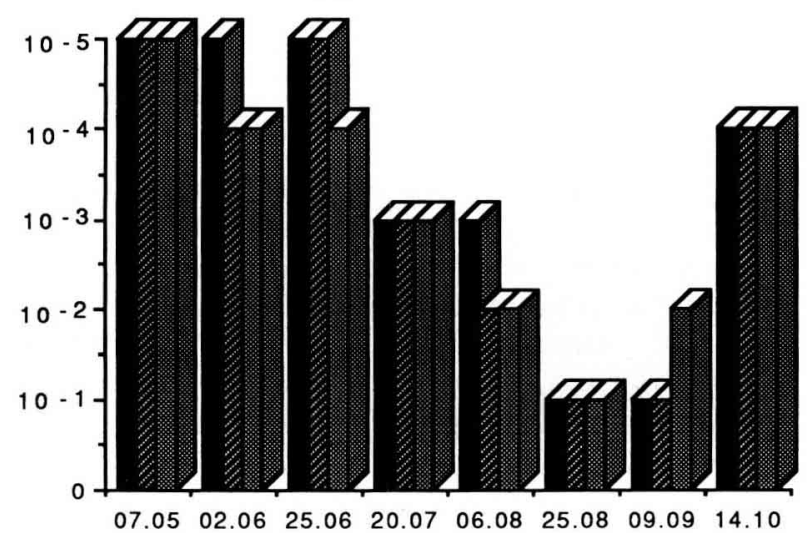

(B) Rupestris du Lot

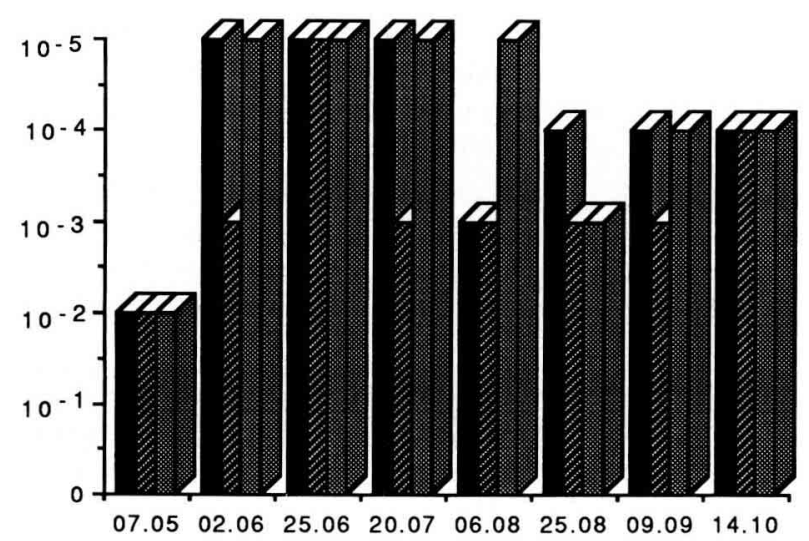

Fig 3. Variation of Elisa end-point dilution for the detection of GFkV over the vegetative period. For detection of GFkV in 3 $\checkmark$ vinifera Muscat d'Alexandrie plants $(A)$ and $3 V$ rupestris plants (B), leaves were harvested at various dates from May 7 th to October 14th. Extracts were diluted from $10^{-1}$ to $10^{-5}$ as described in the Materials and Methods. The height of the diagrams corresponds to the dilution end-point of extracts reacting in Elisa.

\section{Variation of Elisa response during growth}

Large variations in Elisa response were noticed when leaves of vines were analyzed during the entire vegetative period.

The Elisa response decreased rapidly during the hotter summer period, especially in the case of $V$ vinifera Muscat d'Alexandrie (fig 3). Under our conditions, the sensitivity of Elisa was maximal during June and July for $V$ vinifera and $V$ rupestris. This leads to the conclusion that certain periods should be avoided for reliable Elisa detection of GFkV in our climatic conditions: the beginning of the vegetative period for $V$ rupestris and late summer (August and September) for $V$ vinifera (fig 4$)$.
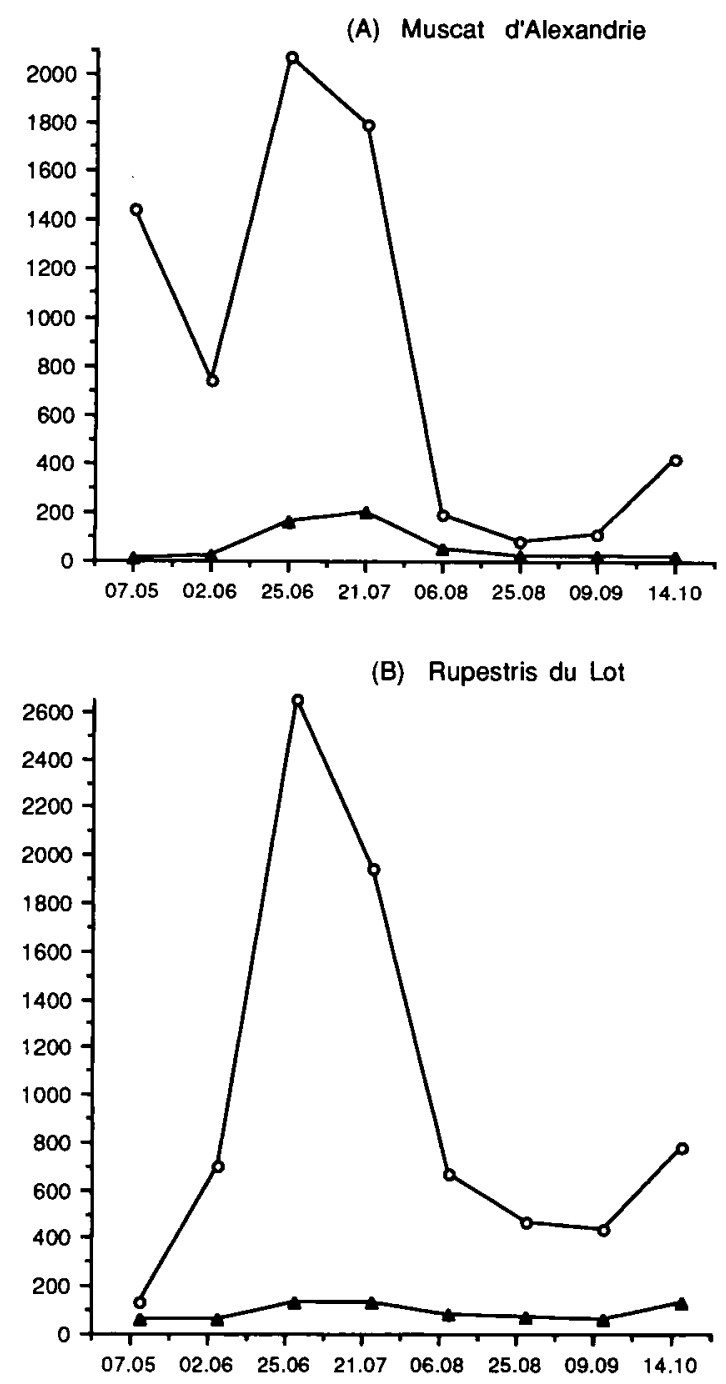

Fig 4. Variation of Elisa response (OD $405 \mathrm{~nm}$ ) in leaf extract of grapevine during the vegetative period. OD variations in Elisa of a $10^{-1}$ dilution of the extracts of leaves of $V$ vinifera Muscat d'Alexandrie $(A)$ and $V$ rupestris $(B)$ harvested at various dates during the vegetative period. Data are $O D$ at $405 \mathrm{~nm}$ after $30 \mathrm{~min}$ incubation of the substrate for diseased (open circles) and healthy (dark triangles) vines. 


\section{DISCUSSION}

In this paper, we confirm that GFkV - an isometric virus previously described by Boulila et al (1990) and Boscia et al (1991b) - is associated with the disease known as fleck (marbrure) and so probably the causal agent of it. Though Koch's postulates have not yet been fully confirmed, we demonstrated a high correlation between the presence of fleck symptoms and the presence of GFkV, both in various grapevine accessions from different geographical origins and in heat-treated vines.

In a series of experiments we have analyzed some factors which could influence reliable detection of GFkV for a routine diagnosis in grapevines, ie when, during the year, a vine should be indexed and what type of tissue should be sampled.

In general, leaves and cortical scrapings were comparable as antigen sources for Elisa; under our conditions, there were no significant differences when comparing tissues from the top or bottom of $V$ vinifera (Muscat d'Alexandrie). Only petioles and leaves from $V$ rupestris showed increasing Elisa readings when harvested from lower to upper parts of the canes. In contrast, Boscia et al (1991b) reported that Elisa readings were highest in the basal leaves of LN 33 and Primitivo di Gioia.

Studying Elisa responses in some $V$ vinifera and $\checkmark$ rupestris, we can conclude that the best period for routine testing is, under our conditions, June and July. The dramatic decrease in Elisa readings during the hottest summer period may bring the response very close to the background level.

Considerable seasonal fluctuations have been reported in the efficiency of detection of nepoviruses in grapevines: in some cases, virus detection was impossible in the hottest periods of the year and was most reliable during intensive growth stages (Kölber et al, 1985) or at full flowering (Bovey et al, 1980; Kölber et al, 1981; Lehoczky et al, 1983, 1984; Rüdel et al, 1983). Under other conditions, detection of nepoviruses was possible by Elisa in grapevine leaves during the whole vegetative period (Walter and Etienne, 1987).

\section{ACKNOWLEDGMENTS}

Grateful thanks are expressed to Prof Martelli and coworkers for supplying the first antiserum, and also to Prof Van Regenmortel for revising the manuscript.

\section{REFERENCES}

Avrameas S (1969) Coupling of enzymes to proteins with glutaraldehyde. Use of the conjugates for the detection of antigens and antibodies. Immunochemistry $6,43-52$

Barlass M, Skene KGM, Woodham RC, Krake LR (1982) Regeneration of virus-free grapevines using in vitro apical cultures. Ann Appl Biol 101, 292-295

Bass P, Legin R (1981) Thermothérapie et multiplication in vitro d'apex de vigne. Application à la séparation ou à l'élimination de diverses maladies de type viral et à l'évaluation des dégâts. $C R$ Acad $A g$ ric Fr 67, 922-933

Boscia D, Martelli GP, Savino V, Castellano MA (1991b) Identification of the agent of grapevine fleck disease. Vitis 30, 97-105

Boscia D, Savino V, Martelli GP, Castellano MA (1991a) Association of the phloem-limited nonmechanically transmissible isometric virus with grapevine fleck disease. In: Proc 10th Meet ICVG (IC Rumbo, R Bovey, D Gonsalves, WB Hewitt, GP Martelli, eds) Ores Publishing, Volos 1990, 173-174

Boulila M, Boscia D, Di Terlizzi B, Castellano MA, Minafra A, Savino V, Martelli GP (1990) Some properties of a phloem-limited non-mechanicallytransmissible grapevine virus. J Phytopathol 129 , 151-158

Bovey R, Brügger JJ, Gügerli P (1980) Detection of fanleaf virus in grapevine tissue extract by enzymelinked immunosorbent assay (Elisa) and immune electron microcopy (IEM). In: Proc 7th Meeting ICVG. Vineland Res Station Canada Agric Branch, Niagara Falls, 259-275

Bovey R, Martelli GP (1992) Directory of Major Virus and Virus-Like Diseases of Grapevines. Description, Historical Review and Bibliography. MFClC, ICVG, pp 111

Goheen AC, Luhn C (1973) Heat inactivation of viruses in grapevines. Riv Patol Vég Ser IV 9, 287-289

Hardie G, Van Regenmortel MHV (1977) Isolation of specific antibody under conditions of low ionic strength. J Immuno Methods 15, 305-314

Kölber M, Beczner L, Pacsa S, Lehoczky J (1985) Detection of grapevine chrome mosaic virus in fieldgrown vines by Elisa. Phytopathol Mediterr 24, 135140

Kölber M, Lehoczky J, Pacsa S, Kobza S (1981) Detection of grapevine fanleaf virus (GFV) with Elisa technique in the leaf samples collected in various phenophases and in deep-frozen leaf extracts. Kertgazdasäg 13, 11-22

Lehoczky J, Kölber M, Beczner L, Pacsa S (1984) Distribution of the grapevine chrome mosaic disease in Hungary and detection of its virus (GCMV) in the leaves of outdoor vines by Elisa technique. Kertgazdasäg 16, 41-52

Lehoczky J, Kölber M, Farkas G (1983) Effect of spring and summer high temperature on detection 
of grapevine fanleaf virus and yellow mosaic virus with Elisa. Kertgazdasäg 15, 37-45

Ottenwaelter MM, Hevin M, Leclair P, Doazan JP, Rives M (1973) Heat therapy eliminates the ability to transmit the causal agent of marbrure in several $V$ vinifera clones and in $V$ rupestris du Lot (St George). Riv Patol Veg Ser IV 9, 281-285

Rüdel M, Alebrand M, Altmayer B (1983) Untersuchungen über den Einsatz des Elisa-Tests zum Nachweis verschiedener Rebviren. Wein Wissenschaft 38, 177-185

Triolo E, Materazzi A (1986) La Maculatura Infettiva della vite: influenza di isolati diversi sull'attitudine alla propagazione vegetativa di Vitis rupestris St George. In: IV Symp Int Sélection Clonale de la Vigne, Changins, 1986. Rech Agron Suisse 3 (26), 320-324
Walter B (1991a) Sélection de la vigne : le dépistage des maladies de la vigne transmissibles par les bois et plants. Bull OIV 727-728, 691-701

Walter B (1991b) New or improved procedures for the detection and identification of viruses or agents of virus-like diseases of grapevine and for diagnosis. In: Proc 10th Meet ICVG (IC Rumbos, R Bovey, D Gonsalves, WB Hewitt, GP Martelli, eds) Ores Publishing, Volos, 1990, 226-238

Walter B, Bass P, Legin R, Martin C, Vernoy R, Collas A, Vesselle $G$ (1990) The use of a green-grafting technique for the detection of virus-like diseases of the grapevine. J Phytopathol 128, 137-145

Walter $B$, Etienne $L$ (1987) Detection of the grapevine fanleaf viruses away from the period of vegetation. J Phytopathol 120, 355-364 